
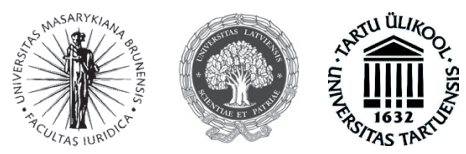

ISSN 1392-6195 (print) ISSN 2029-2058 (online) JURISPRUDENCIJA JURISPRUDENCE 2013, 20(3), p. 1195-1212.

\title{
KIBERNETINIŲ TECHNOLOGIJŲ PANAUDOJIMO GINKLUOTUOSE KONFLIKTUOSE POVEIKIS TARPTAUTINEI HUMANITARINEI TEISEI
}

\author{
Justinas Žilinskas \\ Mykolo Romerio universiteto Teisès fakulteto \\ Tarptautinès ir Europos Sajungos teisès institutas \\ Ateities g. 20, LT-08303 Vilnius, Lietuva \\ Telefonas (+370 5) 2714669 \\ Elektroninis paštas j.zilinskas@mruni.eu
}

Pateikta 2013 m. liepos 15 d., parengta spausdinti 2013 m. rugsèjo 20 d.

doi:10.13165/JUR-13-20-3-17

Anotacija. Šiame straipsnyje nagrinejama, kaip kibernetiniu technologiju panaudojimas ginkluotu konfiktu (kibernetinio karo) kontekstuose veikia tarptautine humanitarine teisę. Konkreciai aptariami trys probleminiai aspektai: ar egzistuojanti tarptautine humanitarine teise iš principo gali reguliuoti tokius naujoviškus reiškinius kaip kibernetinis ar kibernetizuotas ginkluotas konfliktas, antra, kokiq ịtaka kibernetiniu priemoniu panaudojimas daro ginkluoto konflikto sampratai, trečia, kaip kibernetiniu priemoniu atsiradimas ginkluoto konflikto kontekste gali paveikti kombatanto (bei asmens, naudojančio ginkluota jega) instituta. Pirmasis probleminis klausimas teoriškai sprendžiamas gana aiškiai, tačiau antrasis ir trečiasis rodo svarbius esamo teisinio reguliavimo aiškinimo pokyčius, kai nemaža dalis klasikiniu kriteriju praranda prasme, o naujieji kriterijai pasižymi tam tikru teisiniu neapibrëžtumu.

Reikšminiai žodžiai: ginkluotas konfliktas, kibernetinis ginkluotas konfliktas, tarptautine humanitarine teise, kibernetinis ginklas. 


\section{Ivadas}

Kai 2013 m. vasarą prasidèjo DDoS atakos prieš Lietuvos tinklalapius, įskaitant ir populiariausią naujienų portalą delfi.lt, ir Lietuvos pareigūnai prabilo apie kibernetines grèsmes, susirūpinta tiek, kad Lietuvos pirmininkavimo ES Tarybai laikotarpiu $2013 \mathrm{~m}$. tam norima skirti papildomų pajėgumų ${ }^{1}$, net sukurta speciali Vidaus reikalų ministerijos kibernetinio saugumo taryba². Taigi, Lietuvoje jau irgi pripažistama, kad kibernetinių puolimų grèsmės yra aktualios, realios ir esmingai kitokio pobūdžio nei ankstesnès. Ir gana keista, kad Lietuva valstybės lygmeniu tik taip vẻlai susirūpino šiais klausimais. Juk šiuolaikinès visuomenès ir valstybès funkcionavimas jau nebeįsivaizduojamas be informacinių technologijų. Atitinkamai kyla vis daugiau grèsmių, kad netrukus puolimai prieš valstybių informacines sistemas galès sukelti net daugiau žalos nei ịprastinès ginkluotos jëgos panaudojimas.

Kad problema nèra laužta iš piršto, jau patyrẻ mūsų kaimynė Estija - $2007 \mathrm{~m}$. ji tapo kibernetinių puolimų taikiniu ${ }^{3}$, kibernetiniai puolimai užklupo ir Gruziją $2008 \mathrm{~m}$. karo su Rusija metu ${ }^{4}$ o kol kas sẻkmingiausias ir grèsmingiausias kibernetinio puolimo pavyzdys - STUXNET viruso, sugadinusio Irano urano sodrinimo gamyklos centrifugas, sukūrimas ir panaudojimas ${ }^{5}$. Mažesni incidentai, tokie kaip kibernetinis špionažas, duomenų vagystès ir pan., yra pasaulio kasdienybė. Tyrinètojai pastebi, jog kibernetinių priemonių galimybès puikiai pildo vadinamujjų „ketvirtos kartos karų“, kuriems būdinga maoistų „slinkties strategija“ ir alternatyvių hierarchijų kūrimas, gresiantis valstybės teisètumui ir stabilumui, konstruktą .

Galima skirti du variantus, kaip kibernetiniu priemoniu panaudojimas gali pasireikšti ginkluoto konflikto kontekste. Pirmas - tai kibernetiniu priemonių taikymas vykstančio ginkluoto konflikto metu (pavyzdžiui, šalia tradicinių ginkluotos jẻgos panaudojimo būdų pasitelkiamos kibernetinès priemonès - kaip nutiko Gruzijoje, tai būtụ tarsi kibernetizuotas ịprastinis ginkluotas konfliktas), antra, tai ginkluotas konfliktas, vykdomas vien kibernetinėmis priemonėmis (toks atvejis galètų būti STUXNET, jeigu būtų ịrodyta, kad jis buvo sukurtas ir panaudotas valstybių). Ir pirmasis, ir antrasis va-

1 Fuks, E. Išvada po susitikimo su prezidente: vargu ar apsiginsime nuo didesnės atakos. delfi.lt [interaktyvus]. [žiūrèta 2013-06-04]. <http://www.delfi.lt/news/daily/lithuania/isvada-po-susitikimo-su-prezidentevargu-ar-apsiginsime-nuo-didesnes-atakos.d?id=61545466>.

2 İsteigta Kibernetinio saugumo taryba. Lietuvos Respublikos vidaus reikalų ministerija [interaktyvus]. [žiürèta 2013-07-09]. <http://www.vrm.lt/go.php/lit/Isteigta-kibernetinio-saugumo-taryba-/830>.

3 Traynor, I. Russia accused of unleashing cyberwar to disable Estonia. The Guardian [interaktyvus]. [žiūrèta 2013-07-01]. <http://www.guardian.co.uk/world/2007/may/17/topstories3.russia>.

4 Haddick, R. This Week at War: Lessons from Cyberwar I. Foreign Policy [interaktyvus]. [žiūrèta 201307-01]. <http://www.foreignpolicy.com/articles/2011/01/28/this_week_at_war_lessons_from_cyberwar_i $>$.

5 Kushner, D. The Real Story of Stuxnet. IEEE Spectrum [interaktyvus]. [žiūrèta 2013-07-01]. <http:// spectrum.ieee.org/telecom/security/the-real-story-of-stuxnet>.

6 Liles, S.; Dietz, J. E.; Rogers, M.; Larson, D. Applying Traditional Military Principles to Cyber Warfare. 2012 4th International Conference on Cyber Conflict Proceedings. Czosseck, C.; Ottis, R.; Ziolkowski, K. (eds.). Tallinn: NATO CCD COE Publications, 2012, p. 175 [interaktyvus]. [žiūrèta 2013-07-01]. <http:// www.ccdcoe.org/publications/2012proceedings/CyCon_2012_Proceedings.pdf>. 
riantai kelia daug klausimų. Pirmiausia jie diktuojami technologinès specifikos. Kaip visi suprantame, kibernetinio puolimo faktiškai neriboja geografinès valstybių sienos. Yra netgi dar sudètingiau - kaip teisingai pastebejjo po kibernetinių puolimų prieš Estiją elektroninio saugumo firmų specialistai, nustatyti pradinị arba centrinị puolimo šaltinị (o ne jo išnaudojamus užvaldytus kompiuterių tinklus, vadinamus botnet) yra beveik neįmanoma ${ }^{7}$. Be to, netgi paties kibernetinio ,ginklo“ analizė gali užtrukti labai ilgai pavyzdžiui, STUXNET buvo aptiktas 2010 m., ir iki šiol nėra iki galo tikslios informacijos, kas jị sukūrè, daug kas vis dar paremta prielaidomis, maža to, teigiama, kad tai, kas galbūt prasidejjo kaip valstybių kuriamas ginklas, vėliau tapo kriminalinių nusikaltèlių ¡̇kvèpimu ${ }^{8}$. Taigi, temos aktualumas neturètų kelti abejonių.

Kibernetiniai puolimai, kibernetinių priemonių panaudojimas - gana naujas reiškinys. Kyla pagrịstas klausimas, kaip kibernetinio ginkluoto konflikto klausimus spręstų tarptautinè teisè, o dar konkrečiau - tarptautinè humanitarinė teisė? Atsakymų i ši klausimą ieškoma aktyviai. Štai 2012 m. po NATO Kibernetinės gynybos kompetencijos centro (angl. NATO Cooperative Cyber Defence Center of Excellence) egida buvo parengtas „Talino vadovas dèl tarptautinès teisès, taikytinos kibernetiniams karams ${ }^{96 ،}$ (toliau - Talino vadovas), mėginantis atsakyti į daugeli klausimų, susijusių su kibernetiniais konfliktais ${ }^{10}$. Tačiau, nepaisant to, kad mokslininkai pasisako ịvairiais kibernetinio karo klausimais ${ }^{11}$, galutinio aiškumo daugeliu klausimų nėra, todèl tai - vis dar plati erdvė atsakymų paieškai.

Taigi, šio straipsnio tikslas - atsakyti ị klausimą, kokios galimybès de lege lata tarptautinę humanitarinę teisę taikyti kibernetinių karų kontekste, identifikuoti teisinio reguliavimo problemas ir pasiūlyti galimus jų sprendimo būdus. Tyrimo objektas - ịvairūs tarptautinès humanitarinès teisès mechanizmai bei institutai, konkrečiai - ginkluoto konflikto institutas bei asmens, naudojančio ginkluotą jẻgą (kombatanto), institutas. Tyrimo metodai - šaltinių analizès, bylų analizès, sisteminės analizès, istorinis ir kiti.

Šis straipsnis susideda iš trijų teminių dalių: pirmoje aptariamas tarptautinès humanitarinès teisès pritaikomumas naujiems reiškiniams, antroje nagrinėjama, kiek dabartiné ginkluoto konflikto samprata tinkama kibernetinio karo realijoms, trečioje analizuojama, kokie pokyčiai galètų laukti kombatanto sąvokos kibernetinio ginkluoto konflikto kontekste.

Pora pastabų dèl šiame straipsnyje vartojamos terminologijos. Straipsnio tekste žodis ,karas“ vartojamas kaip aprašomasis, bendrosios prasmės terminas, apimantis patị

7 Anderson, N. Massive DDoS attacks target Estonia; Russia accused. Arstechnica.com [interaktyvus]. [žiūrèta 2013-07-01]. <http://arstechnica.com/security/2007/05/massive-ddos-attacks-target-estonia-russiaaccused/>.

8 Kushner, D., supra note 5.

9 Tallinn Manual on the international Law Applicable to Cyber Warfare. Schmitt, M. N. (ed.). Cambridge University Press, 2013.

10 Tiesiog būtų negražu nepasidžiaugti mūsų kaimynų estų tikslingumu, kai 2007 m. kibernetinės atakos prieš Estiją išprovokavo ne šiaip atsaką, o visą iniciatyvų seriją, įskaitant ir NATO Kibernetinès gynybos kompetencijos centro įsteigimą ir minètaji Talino vadovą.

11 Pavyzdžiui, 2012 m. Taline įvyko jau ketvirtoji Kibernetinių konfliktų konferencija, kurios medžiaga šis straipsnis gausiai paremtas. 
ịvairiausią ginkluotos jègos panaudojimo pasireiškimą (tarptautinį ginkluotą konfliktą, netarptautini ginkluotą konfliktą, mišrias arba sunkiai identifikuojamas situacijas, tokias kaip ,antiteroristinès operacijos"), o ne kaip specifinis teisinis terminas, kaip jis buvo suprantamas klasikinèje karo teisèje. Terminas „kibernetinė priemonë“ šiame straipsnyje reiškia bet kokį programinị, technologinị ar kitą sprendimą, skirtą panaudoti kibernetinio karo metu priešui ar oponentui susilpninti, jam pakenkti, įskaitant ir kibernetinius ginklus (t. y. kibernetines priemones, savo poveikiu prilygstančias įprastinių ginklu poveikiui).

\section{Tarptautinès humanitarinès teisès reguliavimo ypatybės ir nauji reiškiniai}

Kibernetiniai puolimai ir apskritai jègos panaudojimas kibernetiniu būdu yra neabejotinai naujas reiškinys. Tuo tarpu tarptautinè teisė nèra toji teisès sistema, kuri i kiekvieną pokytị gali reaguoti tuoj pat, naujomis, tiksliai nukreiptomis ị reiškinį ir aiškiai suformuluotomis teisès normomis. Tarptautinių sutarčių sudarymo ar tarptautinių papročių susiformavimo procesas ilgas, daugialypis ir sudètingas. Ši įžvalga tinka ir tarptautinei humanitarinei teisei. Pavyzdžiui, Ženevos konvencija dẻl karo belaisvių apsaugos (pirmasis jos variantas ${ }^{12}$ ) buvo priimta $1929 \mathrm{~m}$., nors jos poreikis tapo akivaizdus būtent Pirmojo pasaulinio karo metu, 1914-1918 m. Tačiau prireikè 11 metų, kad ji atsirastų popieriuje. Be abejo, jeigu dabar būtų pradèta galvoti apie atskirą konvenciją, skirtą kibernetiniam karui, procesas užtruktų, nors tokių bandymų yra. Bet laiko išsamių naujų normų kūrimui, kaip rodo tarptautiniai incidentai, nėra. Kibernetiniai karai-lygiai toks pats naujoviškas reiškinys, kaip privačių karinių / saugumo kompanijų veikla, nepilotuojamų orlaivių ir autonominių kovos sistemų specialaus reguliavimo nebuvimas. Taigi, reikia atsakyti i principinị klausimą, ar tarptautinè bei tarptautinė humanitarinè teise gali ir yra pajègi reguliuoti kibernetines priemones ginkluoto konflikto kontekste?

Taigi, kalbant apie tarptautinę teisę ir kibernetinio ginkluoto konflikto reguliavimą, vẻlgi galima išskirti dvejopą požiūrį: pirmą, skeptišką, manant, kad tarptautinè teisè, o juo labiau - tarptautinè humanitarinè teise - naujoms realijoms yra visiškai nepritaikyta ir netgi daranti kliūtis nacionaliniam saugumui. Būtent taip pasisako Jeremy A. Rabkinas ir Arielas Rabkinas ${ }^{13}$. Vis dèlto dauguma kitų autorių, įskaitant ir Talino vadovo autorius, mano, kad ir tarptautinès teisès, ir tarptautinès humanitarinès teisès normos taikytinos ir kibernetiniams konfliktams / kibernetinès kovos veiksmams ${ }^{14}$.

$121929 \mathrm{~m}$. Convention relative to the Treatment of Prisoners of War. Geneva, 27 July 1929 [interaktyvus]. [žiūrèta 2013-07-01]. <http://www.icrc.org/applic/ihl/ihl.nsf/Treaty.xsp?documentId=0BDEDDD046FD EBA9C12563CD002D69B1\&action=openDocument>.

13 Rabkin, J. A.; Rabkin, A. To Confront Cyber Threats, We Must Rethink the Law of Armed Conflict. KoretTaube Task Force on National Security and Law [interaktyvus]. [žiūrèta 2013-07-01]. <http://media.hoover. org/sites/default/files/documents/EmergingThreats_Rabkin.pdf $>$. 
Pritartume nuomonei, kad, nepaisant visų naujausių technologinių, visuomeninių, politinių tendencijų, kad pagrindinès keturios Ženevos konvencijos buvo priimtos dar 1949 m. ${ }^{15}$, kai kurios jų normos ateina dar iš XIX a. vidurio ir iš tiesų atrodo beviltiškai pasenusios naujujų ginkluotų konfliktų kontekste, yra tarptautinès humanitarinès teisès normų, pritaikytinų ir kibernetiniams konfliktams. Pirmiausia tai pasakytina apie tarptautinès humanitarinès teisès principus. Dar 1899 m. F. Martensas pateikè išlygą: ,Kol nebus skurtas pilnesnis karo ịstatymų rinkinys, Aukštosios Susitariančios Šalys mano, kad yra svarbu pabrèžti, kad atvejais, kurių neapima šie ju priimti Nuostatai (t. y. II Hagos konvencija dèl sausumos karo įstatymų ir papročių patvirtinti Sausumos karo nuostataiaut. past.), gyventojai ir kovotojai lieka apsaugoti tarptautinès teisés principu, kurie kyla iš civilizuotų tautų ipročių, žmoniškumo įstatymų ir visuomenès sąžinès reikalavimų." 16 Truputi performuluota ši nuostata buvo perkelta ir i 1949 m. Ženevos konvencijų 1977 m. I papildomą protokolą dèl tarptautinių ginkluotų konfliktų aukų apsaugos ${ }^{17}$ (toliau I protokolas) 1 straipsnio 2 dali bei 1949 m. Ženevos konvencijų 1977 m. II papildomo protokolo dèl netarptautinių ginkluotų konfliktų aukų apsaugos ${ }^{18}$ (toliau - II protokolas) preambulę. Taigi, ši formuluote reiškia, kad ginkluoto konflikto metu iš principo yra neįmanoma situacija, kurios tarptautinė humanitarinè teisė visiškai nereguliuotų. Tos pačios nuomonès vėliau laikèsi ir Tarptautinis Teisingumo Teismas Branduolinių bandymų konsultacinėje išvadoje, pasisakęs, jog ,ginkluoto konflikto teisė taikoma visoms ginkluotos kovos formoms ir visiems ginklams, praeities, dabarties ir ateities ${ }^{196}$, kadangi bet kokia kita išvada būtų nesuderinama su humanitariniais principais ir šios teisès tikslu (tai diktuoja tarptautinės humanitarinės teisès paskirtis). Taigi, net jeigu neturime specialiųų normų, visada galime pasitelkti tarptautinès humanitarinès teisès principus: karinès būtinybės, atskyrimo, žmoniškumo, proporcingumo. Šie principai ne tik turi aiškų paprotinị pobūdị, jie užfiksuoti tarptautinės teisės aktuose ir teismų jurisprudencijoje. Todèl atskyrimo principas ir kibernetiniame kare reikš tą patị, ką ir ịprastame kare: visada privaloma skirti karinius ir civilius objektus ${ }^{20}$, net jeigu kibernetinio konflikto metu dèl to gali kilti didelių technologinių sunkumų (pavyzdžiui, kaip pažymi EastWest

151949 m. rugpjūčio 12 d. Ženevos konvencija dèl sužeistujų ir ligonių padèties veikiančiose armijose pagerinimo, Valstybès žinios. 2000, Nr. 63-1905 (I ŽK); 1949 m. rugpjūčio 12 d. Ženevos konvencija „Dèl sužeistujjų, sergančiujų ir skęstančiųų ginkluotųų pajègų narių jūrose padèties pagerinimo“. Valstybès žinios, 2000, Nr. 63-1906 (II ŽK); 1949 m. rugpjūčio 12 d. Ženevos konvencija „Dèl elgesio su karo belaisviais“. Valstybès žinios. 2000, Nr. 63-1907 (III ŽK); 1949 m. rugpjūčio 12 d. Ženevos konvencija „Dèl civilių apsaugos karo metu“. Valstybès žinios. 2000, Nr. 63-1908 (IV ŽK).

16 Hague Convention (II) with Respect to the Laws and Customs of War on Land and its annex: Regulations concerning the Laws and Customs of War on Land. The Hague, 29 July 1899 [interaktyvus]. [žiūrèta 2013-07-01]. <http://www.icrc.org/applic/ihl/ihl.nsf/Treaty.xsp?documentId=CD0F6C83F96FB459C12 563CD002D66A1\&action=openDocument $>$.

171949 m. Ženevos konvencijų papildomas protokolas dèl tarptautinių ginkluotų konfliktų aukų apsaugos (I protokolas). Valstybès žinios. 2000, Nr. 63-1909.

181949 m. Ženevos konvencijų papildomas protokolas dèl tarptautinių ginkluotų konfliktų aukų apsaugos (II protokolas). Valstybès žinios. 2000, Nr. 63-1910.

19 Legality of the Threat or Use of Nuclear Weapons, Advisory Opinion, I.C.J. Reports 1996, para. 86, p. 259.

20 Supra note 17, 52 straipsnis; supra note 18, 13 straipsnis. 
instituto ataskaitos ekspertai, vienas iš svarbių sprendimų, kuriuos valstybės turètų rimtai apsvarstyti, - tai atskyrimas civilinès ir karinès kibernetinès infrastruktūros, kurios šiuo metu yra visiškai susipynusios ${ }^{21}$ ).

Taip pat kibernetinio ginkluoto konflikto metu gali būti taikomos ir konkrečios, tarptautinèse sutartyse ịtvirtintos normos. Pavyzdžiui, tikrai galime teigti, kad kombatanto sąvoka naujujų ginkluotų konfliktų kontekste tam tikrais aspektais yra pasenusi ir jai keliami kai kurie klasikiniai reikalavimai, pavyzdžiui, fiksuotas iš toli matomas ženklas $^{22}$ turi prasmès tik fiziniame mūšio lauke. Kibernetinių priemonių panaudojimo kontekste fizinio mūšio nèra, tad ,iš toli matomas nuolatinis ženklas“ skamba absurdiškai (ypač jeigu pamėgintume tai įsivaizduoti vizualiai); lygiai taip pat atrodo netgi I Protokolo modifikuota, atnaujinta taisyklè, kad puolimo metu užtenka, jog priešininkas mato atvirai nešiojamą ginklą, jeigu asmuo nori išsaugoti kombatanto statusą ir kartu - teisę būti karo belaisviu ${ }^{23}$, tad šių normų taikymas kibernetiniam karui jau neturi prasmès. Bet, pavyzdžiui, specialios taisyklès, kad negalima pulti sanitarinių įstaigų ir dalinių $^{24}$, kad puolimo metu reikia imtis atsargumo priemonių, kad kuo mažiau nukentėtų civiliai objektai ${ }^{25}$ (beje, STUXNET atvejis tuo ir įdomus, kad virusas buvo nutaikytas daryti žalos būtent kariniam (ar bent jau mišrios paskirties) objektui - urano sodrinimo gamyklai $^{26}$ ), kuo puikiausiai taikytina ir ginkluoto konflikto, kurio metu naudojamos kibernetinès priemonès, atveju.

Taigi, galime konstatuoti, kad kibernetinio ginkluoto konflikto metu tarptautinè humanitarinè teisė yra taikytina, nors ir ne visas jos normas įmanoma objektyviai pritaikyti kibernetinio konflikto realijoms, tačiau tai nereiškia, kad kibernetinis konfliktas vyktų teisiniame vakuume. Net jeigu nèra specialaus reguliavimo, pirmiausia taikytini bendrieji tarptautinès humanitarinès teisès (paprotiniai) principai.

\section{Ar vien kibernetinis ginklo panaudojimas gali būti pripažintas ginkluotu konfliktu?}

Tai yra bene ịdomiausias klausimas, kuri kelia kibernetinis ginklas. Norèdami i ji atsakyti turime grį̌̌ti prie gana komplikuotos ginkluoto konflikto sąvokos ir ją įvertinti naujų realijų kontekste. Ginkluoto konflikto terminas tarptautinèje teisèje pirmą kartą

21 Rauscher, K. F.; Korotkov, A. Working towards rules for governing cyber conflict. Rendering the Geneva and Hague Conventions in Cyberspace. New York: EastWest Institute, 2011 [interaktyvus]. [žiūrèta 2013-07-01]. <http://www.ewi.info/working-towards-rules-governing-cyber-conflict>.

22 Supra note 15, 4 str.

23 I protokolas, supra note 17, 44 str.

24 I ŽK, supra note 15,19 str.

25 I protokolas, supra note 17, 57-58 str.

26 Fanelli, R.; Conti, G. A Methodology for Cyber Operations Targeting and Control of Collateral Damage in the Context of Lawful Armed Conflict. 2012 4th International Conference on Cyber Conflict Proceedings, supra note 6, p. 327. 
pasirodė 1949 m. Ženevos konvencijose (2 ir 3 bendrieji straipsniai), tačiau nė viename tarptautinès teisès akte ši sąvoka nebuvo tiksliai apibrèžta.

Ženevos konvencijų komentare, parengtame Tarptautinio Raudonojo Kryžiaus komiteto, akcentuojama, kad bet koks nesutarimas tarp valstybių, sukeliantis ginkluotujų pajėgų panaudojimą, yra ginkluotas konfliktas ${ }^{27}$. Šiame apibrėžime yra du esminiai elementai: subjekto - valstybės, ir priemonès - ginkluotujų pajègų. Šis apibrèžimas buvo patvirtintas ir Tribunolo buvusiai Jugoslavijai spręstoje Tadic byloje ${ }^{28}$, taip pat kitose bylose. I protokolas taip pat tarptautiniais ginkluotais konfliktais nurodė laikyti atvejus, kai tautos, igyvendindamos Jungtinių Tautų Chartijoje įtvirtintą tautų apsisprendimo teisę, kovoja su svetimšalių okupacija, kolonijine priespauda ar rasistiniu režimu ${ }^{29}$, taigi, šalia valstybès atsiranda dar vienas subjektas - tautos, siekiančios nepriklausomybės. Situacija kiek kitokia, kai kalbame apie netarptautini ginkluotą konfliktą. Šiuo atveju, vėlgi daugiausia pagal Jugoslavijos tribunolo jurisprudenciją, tokiu konfliktu laikytina užsitęsusi ginkluota prievarta tarp valstybės ir organizuotų disidentų grupių arba tarp organizuotų disidentų grupių ${ }^{30}$. Taigi, atsiranda papildomi kriterijai, tokie kaip „užsitęsusi ginkluota prievarta“ ir reikalavimas, kad disidentinė konflikto pusė būtų „,organizuota“. Pateikę šiuos kriterijus, turime pažiūrèti, kaip jie siejasi su kibernetinio konflikto ypatybėmis.

Be jokios abejonės, kibernetinè jëga ar ginklas yra priemoné, kuri panaudojama ginkluotos kovos veiksmų metu. Tiek tarptautinis, tiek netarptautinis konfliktas kaip faktinę situacijos vertinimo esmę iškelia pati ginkluotos kovos buvimo momentą. Tačiau atkreiptinas dèmesys, kad tarptautiniam ginkluotam konfliktui nekeliamas joks intensyvumo ar trukmès laike kriterijus, t. y. pirmenybė tarsi atiduodama ginkluotos jègos panaudojimo subjektui. Kitaip tariant, vos ne bet koks ginkluotas susirèmimas panaudojant valstybès ginkluotas pajëgas (bent vienos) prieš kitą bus tarptautinis ginkluotas konfliktas. Taigi, jeigu valstybès ginkluotosios pajėgos panaudos kibernetinị ginklą prieš kitą valstybę, tai gali būti tarptautinio ginkluoto konflikto pradžia. Tokios nuostatos laikomasi ir Talino vadove ${ }^{31}$. Kita vertus, kibernetinès priemonès gali būti labai ịvairaus pobūdžio: pavyzdžiui, DDoS atakos - tai tiesiog serverių darbo trikdymas; tai gali būti slaptos informacijos ieškojimas ir pasisavinimas; tai gali būti ir ịrangos gadinimas. Taigi, kur toji riba, kai kibernetiné priemoné tampa ginklu, savo poveikio jèga galinčiu išprovokuoti ginkluotą konfliktą? Štai čia mes susiduriame su tam tikru požiūriu komplikuota tarptautinès humanitarinès teisès ir tarptautinès viešosios teisés santykio problema, kuri kibernetinio ginklo atveju sukuria papildomų sunkumų.

27 Commentary - Art. 2. Chapter I: General provisions [interaktyvus]. [žiūrèta 2013-07-01]. <http://www. icrc.org/applic/ihl/ihl.nsf/Comment.xsp?viewComments=LookUpCOMART\&articleUNID=41229BA1 D6F7E573C12563CD00519E4A>.

28 Prosecutor v. Dusko Tadic, Decision on the Defence Motion for Interlocutory Appeal on Jurisdiction, IT94-1-A, 2 October 1995, para. 70.

29 I protokolas, supra note 17,1 str.

30 Prosecutor v. Dusko Tadic, supra note 28.

31 Tallinn Manual, Rule 22, supra note 9, p. 71. 
Kaip jau minėjome, tarptautinė humanitarinė teisė techniškai arba materialiai žvelgia ị ginkluotą konfliktą kaip ị ginkluotos jẻgos panaudojimo faktą, kurio kriterijų ar požymių teisès aktuose nedetalizuoja. Toks sprendimas suprantamas, nes bet kokių jègos panaudojimo fakto tikslesnių ribų nustatymas leistų jais galimai manipuliuoti. Tačiau ginkluotos jègos panaudojimą, t. y. ginkluotos jẻgos panaudojimo teisètumą, reguliuoja ne tik tarptautinè humanitarinè teisè (jus in bello), bet ir tarptautinès viešosios teisés dalis, vadinama jus ad bellum (arba jus contra bellum). Būtent joje yra vartojamos tokios sąvokos kaip ,jëga“ ir - mums bene svarbiausia - ,ginkluotas užpuolimas“, îtvirtinta Jungtinių Tautų Chartijos ${ }^{32} 51$ straipsnyje kaip pagrindas teisei i savigyną. Problema ir ta, kad tarptautinè humanitarinè teisè siekia sąmoningai atsiriboti nuo jus ad bellum reguliavimo, vėlgi, dèl skaudžių istorinių pamokų, kai valstybės, net ir vykdydamos plataus masto ginkluotos kovos veiksmus ar okupacijas, nepripažindavo tokių veiksmų ir netaikydavo karo teisès (vienas ryškiausių pavyzdžių - 1939 m. Sovietų Sajungos ivvykdytas Lenkijos užpuolimas).

Teoriškai, kalbėdami vien apie tarptautinę humanitarinę teisę, mes turètume ignoruoti „ginkluoto užpuolimo“ sąvoką, kadangi tarptautinẻ humanitarinė teisė turi savus terminus: bendro pobūdžio ,ginkluotos kovos veiksmai“ (angl. hostilities) bei specifiškai apibréžiamą ,puolimą ${ }^{336 " ~(a n g l . ~ a t t a c k) . ~ T a c ̌ i a u ~, p u o l i m a s “ ~ g i n k l u o t o ~ k o n f l i k t o ~}$ pradžiai nustatyti yra netinkamas, nes jo paskirtis tarptautinėje humanitarinèje teisèje kitokia, jis skirtas apibrěžti taisykles, taikomas puolimo metu, o ne atskleisti konflikto pradžios momentą. Tuo tarpu ,ginkluotos kovos veiksmų“ sąvoka normatyviai neapibrèžta $^{34}$ ir, vèlgi, aktuali ne tik ginkluoto konflikto kvalifikavimo momentui, bet ir visai jo eigai. Taigi, pradinis ginkluoto konflikto momentas, tas, nuo kurio turi būti pradèta visa apimtimi taikyti tarptautine humanitarinè teisè, bent jau aiškumo prasme, sietinas ir su ,ginkluoto puolimo“ sąvoka, kaip minèta, ateinančia iš tarptautinès viešosios teisès ir konkrečiai - savigynos instituto.

Kaip pastebi Michaelis N. Smith'as, dar Nicaragua byloje Tarptautinis Teisingumo Teismas pasakè, jog ginkluotas puolimas turi turèti tam tikrą mastą ir pasekmes ${ }^{35}$. Kitaip tariant, šiuo klausimu mes turime šiek tiek nutolti nuo humanitarinès teisès ir grịžti prie bendrųų ginkluotos jègos draudimo klausimų tarptautinèje teisèje. Iš tiesų, dabartinè tarptautinè teisė ginkluotą užpuolimą vertina daugiau mažiau per ịprastinių ginklų (vadinamų ,kinetiniais“), kurie sukelia pasekmes žmogui ar turtui, prizmę. Kaip rašo Y. Dinsteinas, yra būtinas tam tikras, minimalus ginkluotos jègos lygis, kurị lai-

32 Jungtinių Tautų Chartija. Valstybès žinios. 2002, Nr. 15-557.

33 I protokolo 49 str.: ,„,Puolimai“ reiškia prievartos veiksmus priešininko atžvilgiu, nepaisant, ar tai daroma puolant, ar ginantis."

34 Pagal Tarptautinio Raudonojo Kryžiaus Komiteto ekspertų parengtas Tiesioginio dalyvavimo ginkluotos kovos veiksmuose aiškinamąsias gaires pagal tarptautinę humanitarinę teisę, ginkluotos kovos veiksmai apibrežiami kaip „,kolektyviai konflikto šalių naudojamos priemonès ir būdai pakenkti priešui“. Interpretive guidance on the notion of direct participation in hostilities under international humanitarian law. Melzer, N. (ed.). Geneva: International Committee of the Red Cross, 2009, p. 43.

35 Schmitt, M. N. "Attack" as a Term of Art in International Law: The Cyber Operations Context. 2012 4th International Conference on Cyber Conflict Proceedings, supra note 6, p. 288. 
kytume ginkluotu puolimu ${ }^{36}$, bet iš esmès tas lygis niekur nèra tiksliai apibrèžtas, taigi, jis vertinamas kiekvienu konkrečiu atveju. Ir, kaip juokauja tas pats autorius, jeigu šūvis į kitos valstybės teritoriją pataikè i medi arba tik užmušė karvę, tai nebus ginkluotas užpuolimas ${ }^{37}$. Perkeliant ši klausimą i k kibernetinių priemonių kontekstą, klausimų kyla dar daugiau. Pavyzdžiui, kaip pastebi Louise'as Arimatsu, kenkiančios programos (angl. malware) nesukurtos taip, kad žudytų ar žalotų žmones, ir jos nebūtinai gadins ar naikins turtą. Be to, tai priklauso nuo to, kaip apibrěšim ,turtą““: ar jis apimtų tinklo sistemas, programas ir duomenis ${ }^{38}$ ? Taip, pasekmėmis kibernetinis puolimas irgi gali žudyti - pavyzdžiui, sutrikdžius traukinių kontrolès sistemą ir sukẻlus avariją, kurioje buvo žmonių aukų, tačiau kaip vertintinas kibernetinis puolimas, kuris, pavyzdžiui, paveiks šalies bankų sistemą, bet nieko nenužudys, netgi nesugadins turto? Vis dèlto yra svarstymų, jog kibernetiniai puolimai, skirti sunaikinti ar sugadinti kitos valstybès kritines infrastruktūras, nors ir neatnešantys mirtinos žalos, gali būti laikomi ginkluotu užpuolimu ${ }^{39}$, ir vien tai jau yra didelis tradicinès paradigmos poslinkis. Todèl vadinamasis „kinetinis“ vertinimo kriterijus, kuris reiškia, kad puolimas būtų vertinamas per tai, ar ịprastomis, kinetinėmis priemonėmis (sprogmenys, šaudmenys, raketos, bombos, kt.) galima pasiekti tokio paties rezultato - tinka tik iš dalies. Tai pastebèta jau seniai, ir Michaelis N. Schmitas dar 1999 m. suformulavo platų kibernetinio puolimo vertinimo kriterijų sąrašą, kuris paremtas vadinamuoju „pasekmių požiūriu“ (angl. effects-based approach). Štai kokie pasiūlyti kriterijai:

Sunkumas - puolimo intensyvumas ir apimtis, t. y. kaip plačiai buvo paliesta infrastruktūra, kokią žalą atnešè, kiek pajėgumų naudoja ir kt.;

Trukmé - kaip ilgai puolimas ar jo sukeltos pasekmės truko;

Tikslingumas - kiek neigiamų pasekmių priežastis yra būtent puolimas;

Invazyvumas - kiek glaudžiai puolimas buvo nukreiptas būtent prieš valstybę;

Ǐ̌matuojamumas - kaip lengvai galima nustatyti, apskaičiuoti nuostolius;

Teisètumo prezumpcija - vertinama, ar veiksmas yra teisètas pagal tarptautinę teisę ${ }^{40}$.

Kaip matome, šie kriterijai gana plačiai ir lanksčiai leidžia analizuoti incidentą ir pagal juos net ir puolimai, kurie iš pirmo žvilgsnio neatrodytų kaip ,ginkluoti“, galètų jiems prilygti. Talino vadove šis klausimas sprendžiamas per du lygius: 11 taisyklèje nurodoma: „Kibernetinè operacija yra jègos panaudojimas, kai jos apimtis ir pasekmės yra

36 Dinstein, Y. War Aggression and Self Defence. 4th ed. Cambridge University Press, 2005, p. 173.

37 Ibid., p. 175.

38 Arimatsu, L. A Treaty for Governing Cyber-Weapons: Potential Benefits and Practical Limitations. 2012 4th International Conference on Cyber Conflict Proceedings, supra note 6, p. 97.

39 Melzer, N. Cyber Warfare and International Law. UNIDIR Books and Reports. Geneva: United Nations Institute for Disarmament Research, 2011, p. 15 [interaktyvus]. [žiūrẻta 2013-07-01]. <http://www.isn. ethz.ch/Digital-Library/Publications/Detail/?lng=en\&id=134218>.

40 Schmitt, M. N. Computer Network Attack and the Use of Force in International Law: Thoughts on a Normative Framework. Columbia Journal of Transnational Law. 1998-1999, 37: 885-938, p. 913-915; kriterijų kritinę analizę žr. Ziolkowski, K. Ius ad bellum in Cyberspace - Some Thoughts on the "SchmittCriteria" for Use of Force. 2012 4th International Conference on Cyber Conflict Proceedings, supra note 6, p. 301-307. 
prilygintinos nekibernetinei operacijai, prilygstančiai jègos panaudojimui 41 “, o analizei taikomi minèti kriterijai dar papildomi kriterijumi karinis pobūdis, kuris aiškinamas, kad arba ginkluotosios pajėgos panaudojo kibernetini puolimą, arba jos buvo kibernetinio puolimo taikinys ${ }^{42}$. Tačiau reikia nepamiršti, kad ne kiekvienas jègos panaudojimas yra prilyginamas ginkluotam užpuolimui, kuris turi lemti ir tarptautinès humanitarinès teisès veikimą visa apimtimi, todèl Talino vadovo 13 taisyklè (kalbanti apie savigyną), nurodo, kad savigyna galima tik tokiu atveju, jeigu kibernetinis užpuolimas prilygo ginkluotam užpuolimui.

Taigi, vis dèlto ginkluotos jègos panaudojimo vertinimas, bent jau pradiniame etape, vykdomas per jus ad bellum prizmę. Teoriškai neįmanoma, kad ginkluotas užpuolimas pagal jus ad bellum nebūtų ginkluotas konfliktas. Kita vertus, nėra aiškaus atsakymo, ar mažesnio masto užpuolimas (t. y. mažesnio masto ginkluotos jègos panaudojimas) negalètų būti ginkluotas konfliktas pagal ,ginkluotos kovos veiksmų“ (angl. hostilities) požymį, kuris jau priklauso tik tarptautinei humanitarinei teisei. Čia svarbu atsiminti, kad ginkluoto konflikto galimo apibrèžimo tikslas yra kitoks nei ginkluoto užpuolimo - kaip jau minėjome, ginkluotas užpuolimas leidžia imtis savigynos (atsakomojo ginkluotos jėgos naudojimo), tuo tarpu ginkluoto konflikto, kurị sukelia ginkluotos kovos veiksmai, sampratos pirminè paskirtis - jo aukų apsauga. Ir etiškai, ir teoriškai galima būtų samprotauti, kad ginkluoto konflikto aukų apsauga turètų atsirasti visais atvejais, kai atsiranda ginkluotos jègos panaudojimo aukų (sužeistieji, žuvusieji) - tai atitinka ir Ženevos konvencijos kūrèjų siekius ${ }^{43}$. Talino vadovo kūrèjai irgi nurodo, kad ,riba turi būti pakankamai žema“"44, kaip tokio atvejo pavyzdys nurodomas gaisro sukèlimas kibernetinėmis priemonėmis kariniame objekte. Mūsų nuomone, vertindami ,ginkluotos kovos veiksmus“ kibernetinių priemonių kontekste kaip ginkluoto konflikto pradžią, mes taip pat galėtume naudoti „Schmith’o kriterijus“, minėtus prie ,ginkluoto užpuolimo“. Tačiau čia susiduriame ir su klausimu, kad, vienai pusei pradejjus ginkluotą konfliktą, kita pusè turi teisę ir gintis, ir užpuoliką pulti. Taigi, pagal naujajị požiūrị, siūlomą doktrinos atstovų, gali būti taip, kad veiksmai, nesukèlę mirčių ar turto fizinio sunaikinimo (pavyzdžiui, sutrikdyta ar net sunaikinta informacinẻ bankininkystès sistema), gali sulaukti ir kinetinio atsako, kuris tokias pasekmes sukels. Vadinasi, galima situacija, kai tarptautinè humanitarinė teisè pradès veikti visa apimti ir dar nesant aukų. Galbūt tai ir gerai, ypač atsižvelgiant ị šios teisès turimą prevencinę aukų apsaugos funkciją.

Tačiau taip pat reikia atkreipti dėmesį, kad ginkluotos kovos veiksmų vertinimas svarbus ir kituose, ne tik savigynos ar ginkluoto konflikto pradžios kontekstuose (pavyzdžiui, jis svarbus ir ginkluoto konflikto procese, kai i ginkluotos kovos veiksmus įsitraukia civiliai, tiesiogiai dalyvaujantys ginkluotoje kovoje (pavyzdžiui, reikia įvertinti, ar civilio atliktas veiksmas buvo, ginkluotos kovos veiksmai“‘); netarptautinio ginkluoto konflikto kontekste (kiek disidentai pajègūs vykdyti kovos veiksmus).

Tallinn Manual, supra note 9, p. 47.

42 Ibid., p. 51.

43 Commentary - Art. 2. Chapter I: General provisions, supra note 27. 
Netarptautinio ginkluoto konflikto atveju ginkluotos kovos veiksmams turime dar papildomą kriterijų - užsitęsusi ginkluota prievarta ${ }^{45}$ (angl. protracted armed violence), t. y. keliamas ir tam tikras prievartos intensyvumo kriterijus, kuris šiuo atveju apibrèžiamas labiau prievartos trukme, o ne mastu ${ }^{46}$. Tačiau niekur toji trukmė nėra nusakyta tiksliai ir vèl paliekama konkretaus atvejo analizei. Haradinaj byloje Jugoslavijos tribunolas pasisakè, kad intensyvumą atspindi susiremimų skaičius, trukmè, aktyvumas, naudojamos ginkluotès ir ịrangos rūšys, pajėgų dydis, aukų skaičius, Jungtinių Tautų Saugumo Tarybos įsikišimas ir pan. ${ }^{47}$ Turbūt netgi galime teigti, kad netarptautinio ginkluoto konflikto kvalifikavimui prievartos, ,tinkamos“" netarptautinio ginkluoto konflikto kvalifikavimui, trukmès nustatymui, svarbesnis yra ne materialusis, o būtent subjekto kriterijus, kadangi tik kai disidentai pasiekia tam tikrą organizuotumo lygị ir jų veiksmų nebegalime vertinti kaip sporadiškų prievartos veiksmų, riaušių ar neramumų ${ }^{48}$, galime pradèti kalbèti apie netarptautinį ginkluotą konfliktą. Taigi, netarptautinio ginkluoto konflikto metu toji „užsitęsusi prievarta“ turi kilti iš specialaus subjekto - organizuotų disidentų. Organizuotumo klausimu Jugoslavijos tribunolas Haradinaj ir ypač Limaj bylose akcentavo, jog disidentų organizuotumą nurodo komandinių struktūrų buvimas, disciplinos taisyklès, grupès veikimas kaip vieningo subjekto, gebančio planuoti, koordinuoti, vykdyti karines operacijas ${ }^{49}$. Todèl dabar grị̌kime prie subjektų klausimų ir jų ypatybių kibernetinių priemonių panaudojimo kontekste.

Taigi, faktinis ginkluotos jëgos panaudojimas - tik vienas ginkluoto konflikto, tiek tarptautinio, tiek netarptautinio, požymis. Bet taip pat svarbu ir kas ginkluotą jègą naudoja. Tarptautinio ginkluoto konflikto atveju mažiausiai abejonių kyla tuomet, kai ginkluotą jègą naudoja valstybès ginkluotosios pajègos, su kuriomis mes ịpratę sieti ginklus. Tačiau kibernetinių priemonių kontekste (taip pat ir, pavyzdžiui, nepilotuojamų aparatų) neretai veikia ir kiti subjektai - pavyzdžiui, CŽV. Talino vadovo kūrèjų manymu, jie taip pat laikytini valstybès ginkluotujų pajègų dalimi ${ }^{50}$, nors ịprastai tarptautinė humanitarinė teisė būtent valstybių vidaus teisei palieka apibrėžimą, kas yra „ginkluotosios pajėgos“. Matyt, Talino vadove tokia išvada daroma remiantis valstybių atsakomybės principais, kadangi tokiais atvejais šie subjektai tarsi vykdo priskirtas funkcijas, kurios paprastai priklauso kitoms institucijoms, tačiau nuo to neturètų pakisti vertinimas. Sudėtingiau, kai i jẻgos naudotojų ratą patenka subjektai, kurių ryšys su valstybe ar jos institucijomis būna visai kitokio pobūdžio. Pavyzdžiui, pasitelktos privačios kompanijos, kiti ịvairūs ,nevalstybiniai subjektai“ ar net tiesiog kompiuterių entuziastai, individų grupès, net pavieniai individai. Pavyzdžiui, $2007 \mathrm{~m}$. kai buvo pradėti kibernetiniai puolimai prieš Estijos valstybès ir bankų tinklalapius, tai darè ir aktyvistai, vedami pačių ịvairiausių motyvų ${ }^{51}$. Tarptautinėje teisèje yra mechanizmai, kai valstybė

45 Prosecutor v. Dusko Tadic, supra note 28.

46 Moir, L. The Law of Internal Armed Conflict. Cambridge University Press, 2004, p. 43.

47 Prosecutor v. Haradijan, Trial Chamer Judgement, IT-04-84-T, 3 April 2008, para. 49.

48 Šiuo atveju remiamasi II protokolo 1 straipsniu.

49 Prosecutor v. Limaj, Trial Chamber Judgement, IT-03-66-T, November 20, 2005, paras. 94-129.

$50 \quad$ Tallinn Manual, supra note 9, p. 75.

51 Kadangi 2007 m. Estijos įvykius interneto erdvejje teko stebėti ,iš arti“, galime patvirtinti, kad bent dalis ,aktyvistų“, organizavusių ịvairias kibernetines priemones, buvo tiesiog Rusijos piliečiai, užsimanę 
laikoma atsakinga ir už privačių asmenų veiksmus (pavyzdžiui, jeigu valstybè prisiima atsakomybę ar jeigu asmenys de facto veikè kaip valstybės organas ${ }^{52}$ ), tačiau tai vis dèlto yra išimtis, o ne taisyklè. Tad bet kuriuo atveju, norèdami vienokio ar kitokio subjekto kibernetinio puolimo veiksmus priskirti valstybei ginkluoto konflikto kontekste, turèsime remtis iprastiniais efektyvios kontrolès ${ }^{53}$ ar bendrosios kontrolès testais, kurie šiuo metu koegzistuoja skirtingų tarptautinių teismų praktikoje. Jeigu šių veikų valstybei priskirti negalèsime, tuomet negalèsime konstatuoti tarptautinio ginkluoto konflikto.

Ir čia, mano manymu, gali kilti rimtas klausimas, ar minèti testai pakankami kibernetinio konflikto atvejais. Pavyzdžiui, bendrosios kontrolès testas reikalauja, kad valstybe turi koordinuoti, kartu planuoti karines operacijas su tam tikra grupuote (nevalstybiniu subjektu) ir pan. ${ }^{54}$ Tačiau, kaip rodo ir Estijos situacijos pavyzdys, valstybès įsikišimas gali būti ir gana nedidelis, o kibernetinès priemonès - pakankamai grèsmingos, ypač nepasirengusiam puolimo objektui. Juolab, kibernetinèms priemonèms faktiškai neturint geografinių apribojimų, priskyrimo klausimas tampa ypatingai sudètingas, pirmiausia technologiniu požiūriu, o jis egzistuojantiems priskyrimo būdams irgi nepalankus: kibernetinis puolimas gali būti suorganizuotas per tūkstančius užvaldytų kompiuterių iš pačių įvairiausių pasaulio vietų. Be to, kaip jau buvo minèta, išanalizuoti atakų šaltinị, programinès įrangos kūrèjus reikia daug laiko. Pavyzdžiui, ịtariama, kad prie STUXNET viruso kūrimo galèjo prisidèti specialiosios JAV ir Izraelio tarnybos, bet konkrečių ịrodymų iki šiol nèra, tik loginès prielaidos ${ }^{55}$.

Ypač sudètingas subjekto klausimas gali kilti netarptautinio ginkluoto konflikto kontekste. Kaip jau minejome ir kaip pažymėta Tadic ir kitose Tribunolo buvusiai Jugoslavijai bylose, netarptautinio ginkluoto konflikto atveju disidentai turi būti ,organizuoti“،. Organizuotumas šiuo atveju taip pat apima, kad disidentai yra pajègūs ịyvendinti bent jau bendrą Ženevos konvencijų 3-iajị straipsnị (minimalias humanitarines garantijas $)^{56}$. II protokolas ${ }^{57}$ reikalauja, kad disidentai dar ir kontroliuotų teritoriją ${ }^{58}$, tačiau šiuolaikinių ginkluotų konfliktų kontekste, matyt, tai pamažu taps fakultatyviu, o ne privalomu požymiu. „Kliba“ ir kitas įprastinis kriterijus - geografinis - t. y. kad netarptautinis ginkluotas konfliktas turètų vykti vienos valstybès teritorijoje (pavyzdžiui, būtent prie šios išvados prièjo JAV Aukščiausiasis teismas Hamdan byloje ${ }^{59}$ ). Kita vertus,

„nubausti“ Estiją už „Bronzinio kario“ monumento iškeldinimą. Kitaip tariant, tai buvo tarsi „pilietinè akcija“, kuriai, žinoma, netrukdè ir Rusijos vyriausybè.

52 Žr. (Draft) Articles on Responsibility of State for Internationally Wrongful Acts, UN Doc. A/RES/56/83 (12 Dec. 2001), Art. 5, 8, 9 .

53 Military and Paramilitary Activities in and against Nicaragua (Nicaragua v. United States of America). Merits, Judgment. I.C.J. Reports 1986, p. 14, paras. 218-220.

54 Prosecutor v. Dusko Tadic, Appeals Chamber Judgement, IT-94-1-AR72, 27 February 2001, paras. 131, 145.

55 Cavelty, M. D. The Militarisation of Cyberspace: Why Less May Be Better. 2012 4th International Conference on Cyber Conflict Proceedings, supra note 6, p. 148.

56 Moir, L., supra note 46, p. 43.

57 Tačiau reikia nepamiršti, kad II protokolas reguliuoja siauresnę situaciją nei ŽK bendras 3 str.

58 II protokolas, supra note 18, 1 str.

59 Hamdan v. Rumsfeld 126 S Ct 2749 (2006). 
jau ir dabar disidentų organizuotumo kriterijus yra nebeaiškus. Pavyzdžiui, JAV teismų praktikoje buvo pripažinta, kad JAV ir Al Qaeda yra netarptautinio ginkluoto konflikto šalys, nors Al Qaeda yra apibūdinama kaip ,palaidas tinklas“ (angl. loose network), ir apie kažkokią aiškią struktūrą, discipliną ar atsakomybę kalbėti ypač sudėtinga. Dar sudètingiau bus, kai reikès vertinti vien kibernetinių kovotojų tinklus. Atsižvelgiant i tokius fenomenus kaip atvirojo kodo bendruomenės, jau minėtą ,pilietinị aktyvizmą“, identifikuoti tokius darinius kaip organizuotą subjektą būtų itin drąsu. Mūsų manymu, ìvertinant visą netarptautinio ginkluoto konflikto požymių neapibrèžtumą, labai maža tikimybè, kad ji galètų sukelti vien kibernetinès priemonės.

\section{3. „Kibernetinio kovotojo“ statuso problema}

Tarptautinè humanitarinè teisè numato du pagrindinius asmenų statusus: tai kombatantas ir civilis. Pagrindinis mums aktualus jų skirtumas - kombatantas turi teisę dalyvauti ginkluotoje kovoje ir būti puolamas, civilis - turi būti saugomas ir neturi teisès dalyvauti ginkluotoje kovoje. Netarptautinio ginkluoto konflikto situacijoje kombatanto sąvokos mes nevartojame, bet iš esmès vis tiek tenka spręsti, kada prieš asmeni galima naudoti ginkluotą jègą.

Kibernetinio konflikto situacijoje turbūt nekils didelių problemų, kai kalbėsime apie aiškius kombatantus - t. y. valstybès ginkluotujų pajėgų narius, kurie naudotų kibernetini ginklą. Tačiau, kaip jau ne kartą minèta, kibernetinès priemonès yra kompleksinis reiškinys. Pavyzdžiui, jeigu kalbėtume apie kenkiančią programą, prie jos gali dirbti daug žmonių: vieni projektuoja programos architektūrą, antri rašo kodą ar jo dalis, treti sukuria galimybes, kaip įdiegti ją i apsaugotas sistemas, ir pan. Galimas daiktas, kad šie asmenys bus iš skirtingų institucijų ir dažnai net nežinos, kam bus naudojamas jų galutinis produktas. Tad kas bus atsakingas už tokị kibernetinị ginklą? Jị panaudojęs, ji sukūręs, sukūręs jo dalị ar pan.? Be to, kibernetiné kova yra itin palanki aplinka ị kovą įsitraukti bet kam. Net ir žmogui, pakankamai neįvertinančiam savo dalyvavimo svarbos. Kaip jau minejjome, kibernetinio karo metu prasmę praranda net ir elementariausi klasikiniai kombatanto statuso reikalavimai, įtvirtinti I Protokole (nešioti ginklą atvirai karinès operacijos metu kai mato priešas ${ }^{60}$ ). Kas juos pakeis, kai reikès spręsti, ar galima prieš asmeni naudoti ginkluotą jègą ir koki statusą jam suteikti? Teisinio manevro laisvé čia nėra plati. Seanas Wattsas siūlo, kad afiliacija su valstybe (matyt, platesnio supratimo nei dabar reikalaujama iš kombatanto) turètų tapti pagrindiniu kriterijumi ${ }^{61}$. Mes prognozuotume, kad tais atvejais, kai asmuo dalyvaus kibernetiniame konflikte, bet nepriklausys valstybès ginkluotosioms pajëgoms, teks remtis arba ginkluotos grupès nario, vykdančio nuolatinę kovinę funkciją (,nuolatinès kovinès funkcijos“"), koncepcija, arba vadinamaja ,civilio, tiesiogiai dalyvaujančio ginkluotos kovos

60 I protokolas, supra note 17,44 str.

61 Watts, S. The Notion of Combatancy in Cyber Warfare Watts. 2012 4th International Conference on Cyber Conflict Proceedings, supra note 6, p. 247. 
veiksmuose", koncepcija. Pirmoji koncepcija savo esme panaši ị kombatanto (funkciškai: nuolatinė priklausomybė grupei (verbavimas, integracija ị struktūrą, paklusimas i̊sakymams, dalyvavimas operacijose, faktinis ginkluotos jëgos naudojimas ${ }^{62}$ ), tačiau toks asmuo vis tiek neigyja kombatantui taikomos teisinès apsaugos, o tik praranda apsaugą nuo puolimo. Tokių asmenų pavyzdžiu kibernetinio konflikto kontekste galètų būti žmonès, kurie tikslingai suvienija pastangas atlikti kovos veiksmus kibernetinėje erdvèje. Sakyčiau, kad per šį statusą reikètų vertinti ir privačių karinių / saugumo kompanijų personalą, jeigu jis ịtraukiamas ị kibernetinès kovos veiksmus ir jeigu valstybė kitaip neapibrèžè jų statuso, tarkim, pagal nacionalinę teisę. Tuo tarpu civilio, tiesiogiai dalyvaujančio ginkluotos kovos veiksmuose, koncepcija, kildinama iš I protoko$10^{63}$, apibrèžia situacijas, kai civilis tam tikram momentui ịsitraukia ị ginkluotą kovą ir to pagrindu praranda apsaugą nuo puolimo. Šiuo atveju vertinama, ar civilio veiksmai atitiko reikiamą žalos lygị (t. y. žala turi neigiamai paveikti karines operacijas ar pajėgumus arba sukelti saugomų asmenų ar objektų mirtį, sužalojimus, sunaikinimą); turejjo tiesioginị priežastinị ryši (ryšys tarp veikos ir žalos) ir sąsają su ginkluota kova (t. y. aktu siekiama padèti vienai konflikto šaliai ir trukdyti kitai) ${ }^{64}$. Tokio asmens pavyzdžiu galètų būti kompiuterių entuziastas, epizodiškai nusprendęs padèti kuriai nors kovojančiai pusei (nesvarbu, iš idèjos ar už atlyginimą), pavyzdžiui, nutupdyti nepilotuojamą skraidantị aparatą. Toks asmuo teisètu taikiniu bus tik tol, kol veikia konflikto pusès naudai.

Žinoma, šios koncepcijos nèra idealios išeitys ${ }^{65}$, kita vertus, jų gairès leidžia šiek tiek aiškiau apibrěžti jègos naudojimo prieš tokius asmenis ribas ir kriterijus. „Nuolatinès kovinès funkcijos" koncepciją susiejus su karo įstatymų ir papročių laikymųsi, galima būtų svarstyti apie kvazikombatanto statusą, nors valstybès iki šiol tokiems asmenims suteikdavo šį statusą tik konkrečiose situacijose (pavyzdžiui, netraukdavo baudžiamojon atsakomybėn vien už ginkluotos jègos panaudojimą, sulaikytiems taikydavo statusą, analogišką karo nelaisvei). Vertètų pabrèžti, jog realus kovojančių ir nekovojančių atskyrimas kibernetiniame konflikte pirmiausia aktualus kibernetinių kovotojų atžvilgiu yra tik tada, kai prieš juos naudojama kinetinè jèga (pavyzdžiui, identifikuojamas atakų centras ir jis puolamas ịprastinėmis karinėmis priemonėmis). Wattsas teisingai pastebi, kad didžiausias pavojus kibernetiniame kare kyla ne dèl kovotojų / civilių neatskyrimo, o dèl to, kad kibernetinejje erdveje nèra aiškiai atskirtos karinès ir civilinės infrastruktūros, be to, čia kaip niekur kitur patogu civiliais ištekliais maskuoti karinius objektus ${ }^{66}$.

62 Interpretive guidance, supra note 34, p. 43.

63 I protokolas, supra note 17,53 str. $3 \mathrm{~d}$.

64 Interpretive guidance, supra note 34, p. 46-68.

65 Žr. Prescott, J. M. Direct Participation in Cyber Hostilities: Terms of Reference for Like-Minded States? 2012 4th International Conference on Cyber Conflict Proceedings, supra note 6, p. 255-259.

66 Watts, S., supra note 61, p. 247. 


\section{Išvados}

Kibernetiniai ginkluoti konfliktai arba kibernetiniu priemonių panaudojimas tradiciniame ginkluotame konflikte, naujas reiškinys vien tik dèl to, kad tai - naujas reiškinys, nėra teisiškai nereguliuojamas. Tarptautinè humanitarinè teisė jau turi mechanizmus, leidžiančius jos normas (ypač paprotinius principus) taikyti naujiems fenomenams. Tačiau, žinoma, atsiranda ir klausimų, kuriuos dabartinis reguliavimas gali išspręsti tik labai apytikriai. Vienas iš esminių klausimų - ar vien kibernetinėmis priemonèmis galima sukelti ginkluotą konfliktą. Atsižvelgiant ị tai, kad tikslaus reguliavimo šiais klausimais nèra netgi ịprastinių ginkluotos kovos veiksmų atveju, kibernetinis „mūšio laukas“ ši klausimą daro dar sudètingesnį. Vis dèlto atrodo, kad ginkluoto konflikto kvalifikavimo paradigma patirs pokyčių, paremtų „pasekmių požiūriu“, t. y. ateityje ginkluotą konfliktą vertinsime ne tik per tradicinę žalos žmonèms / turtui, sukeltos kinetinès jègos, prizmę, bet teks pasitelkti ir papildomus kriterijus, leidžiančius ginkluotu konfliktu laikyti situacijas, nesukeliančias tradicinès žalos. Manytume, didžiausia problema, jog šis pokytis gali sudaryti sąlygas būtent kinetinès jègos panaudojimui, kai ị virtualų puolimą nebus teisinių kliūčių atsakyti realia jèga. Kita vertus, tai pastūmèja tarptautinę humanitarinę teisę arčiau prevencinès paskirties ịgyvendinimo: pradèti aukas saugoti anksčiau, nei jos realiai atsirado. Neabejotina, kad kibernetinių ir kibernetizuotų ginkluotų konfliktų kontekste pokyčius patirs ir kiti institutai, konkrečiai - kombatanto (bei asmens, naudojančio ginkluotą jègą) institutas. Klasikiniai identifikavimo kriterijai kibernetiniame „mūšio lauke“ tampa nebetinkami, o iš esamos reguliavimo bazès labiausiai tam tiktų pritaikyti „nuolatinio kovotojo“ bei „civilio, tiesiogiai naudojančio ginkluotą jègą“ koncepcijas. Tiesa, šios koncepcijos yra išvestinès iš skurdaus reguliavimo, tačiau jos suformuluoja svarbias gaires, leidžiančias spręsti tokių asmenų apsaugos klausimus.

\section{Literatūra}

$1929 \mathrm{~m}$. Convention relative to the Treatment of Prisoners of War. Geneva, 27 July 1929 [interaktyvus]. [žiūrèta 2013-07-01]. <http:// www.icrc.org/applic/ihl/ihl.nsf/Treaty.xsp? documentId=0BDEDDD046FDEBA9C125 63CD002D69B1\&action=openDocument $>$. 1949 m. rugpjūčio 12 d. Ženevos konvencija „Dèl elgesio su karo belaisviais“. Valstybès žinios. 2000, Nr. 63-1907.

1949 m. rugpjūčio 12 d. Ženevos konvencija „Dèl sužeistujų, sergančiųų ir skęstančiųjų ginkluotųų pajègų narių jūrose padèties pagerinimo“. Valstybés žinios. 2000, Nr. 631906.
1949 m. rugpjūčio 12 d. Ženevos konvencija „Dèl civilių apsaugos karo metu“. Valstybès žinios. 2000, Nr. 63-1908.

1949 m. rugpjūčio 12 d. Ženevos konvencija dèl sužeistujų ir ligonių padèties veikiančiose armijose pagerinimo. Valstybès žinios. 2000, Nr. 63-1905.

1949 m. Ženevos konvencijų papildomas protokolas dèl tarptautinių ginkluotų konfliktų aukų apsaugos (I protokolas). Valstybès žinios. 2000, Nr. 63-1909.

1949 m. Ženevos konvencijų papildomas protokolas dèl tarptautinių ginkluotų konfliktų aukų apsaugos (II protokolas). Valstybès žinios. 2000, Nr. 63-1910. 
Anderson, N. Massive DDoS attacks target Estonia; Russia accused. Arstechnica.com [interaktyvus]. [žiūrèta 2013-07-01]. <http:// arstechnica.com/security/2007/05/massiveddos-attacks-target-estonia-russia-accused/>.

Arimatsu, L. A Treaty for Governing CyberWeapons: Potential Benefits and Practical Limitations. 2012 4th International Conference on Cyber Conflict Proceedings. Czosseck, C.; Ottis, R.; Ziolkowski, K. (eds.). Tallinn: NATO CCD COE Publications, 2012.

(Draft) Articles on Responsibility of State for Internationally Wrongful Acts, UN Doc. A/ RES/56/83 (12 Dec. 2001).

Cavelty, M. D. The Militarisation of Cyberspace: Why Less May Be Better. 2012 4th International Conference on Cyber Conflict Proceedings. Czosseck, C.; Ottis, R.; Ziolkowski, K. (eds.). Tallinn: NATO CCD COE Publications, 2012.

Commentary - Art. 2. Chapter I: General provisions [interaktyvus]. [žiūrèta 2013-0701]. <http://www.icrc.org/applic/ihl/ihl.nsf/ Comment.xsp?viewComments $=$ LookUpCO MART\&articleUNID=41229BA1D6F7E57 3C12563CD00519E4A>.

Dinstein, Y. War Aggression and Self Defence. 4th ed. Cambridge University Press, 2005.

Fanelli, R.; Conti, G. A Methodology for Cyber Operations Targeting and Control of Collateral Damage in the Context of Lawful Armed Conflict. 2012 4th International Conference on Cyber Conflict Proceedings. Czosseck, C.; Ottis, R.; Ziolkowski, K. (eds.). Tallinn: NATO CCD COE Publications, 2012.

Fuks, E. Išvada po susitikimo su prezidente: vargu ar apsiginsime nuo didesnès atakos. delfi.lt [interaktyvus]. [žiūrèta 201306-04]. < <http://www.delfi.lt/news/daily/ lithuania/isvada-po-susitikimo-su-prezidente-vargu-ar-apsiginsime-nuo-didesnesatakos.d?id $=61545466>$.

Haddick, R. This Week at War: Lessons from Cyberwar I. Foreign Policy [interaktyvus]. [žiūrèta 2013-07-01]. <http://www.foreignpolicy.com/articles/2011/01/28/this_week_ at_war_lessons_from_cyberwar_i $>$.

Hague Convention (II) with Respect to the Laws and Customs of War on Land and its annex: Regulations concerning the Laws and Customs of War on Land. The Hague, 29 July 1899 [interaktyvus]. [žiūrèta 201307-01]. <http://www.icrc.org/applic/ihl/ihl. nsf/Treaty.xsp?documentId=CD0F6C83F96 FB459C12563CD002D66A1\&action $=$ open Document>.

Hamdan v. Rumsfeld 126 S Ct 2749 (2006).

Interpretive guidance on the notion of direct participation in hostilities under international humanitarian law. Melzer, N. (ed.). Geneva: International Committee of the Red Cross, 2009.

Isteigta Kibernetinio saugumo taryba. Lietuvos Respublikos vidaus reikalų ministerija [interaktyvus]. [žiūrèta 2013-07-09]. <http:// www.vrm.lt/go.php/lit/Isteigta-kibernetiniosaugumo-taryba-/830>.

Jungtinių Tautų Chartija. Valstybès žinios. 2002, Nr. 15-557.

Kushner, D. The Real Story of Stuxnet. IEEE Spectrum [interaktyvus]. [žiūrèta 201307-01]. <http://spectrum.ieee.org/telecom/ security/the-real-story-of-stuxnet>.

Legality of the Threat or Use of Nuclear Weapons, Advisory Opinion, I.C.J. Reports 1996.

Liles, S.; Dietz, J. E.; Rogers, M.; Larson, D. Applying Traditional Military Principles to Cyber Warfare. 2012 4th International Conference on Cyber Conflict Proceedings. Czosseck, C.; Ottis, R.; Ziolkowski, K. (eds.). Tallinn: NATO CCD COE Publications, 2012.

Melzer, N. Cyber Warfare and International Law. UNIDIR Books and Reports. Geneva: United Nations Institute for Disarmament Research, 2011.

Military and Paramilitary Activities in and against Nicaragua (Nicaragua v. United States of America). Merits, Judgment. I.C.J. Reports 1986.

Moir, L. The Law of Internal Armed Conflict. Cambridge University Press, 2004.

Prescott, J. M. Direct Participation in Cyber Hostilities: Terms of Reference for LikeMinded States? 2012 4th International Conference on Cyber Conflict Proceedings. Czosseck, C.; Ottis, R.; Ziolkowski, K. (eds.). Tallinn: NATO CCD COE Publications, 2012. 
Prosecutor v. Dusko Tadic, Appeals Chamber Judgement, IT-94-1-AR72, 27 February 2001.

Prosecutor v. Dusko Tadic, Decision on the Defence Motion for Interlocutory Appeal on Jurisdiction, IT-94-1-A, 2 October 1995.

Prosecutor v. Haradijan, Trial Chamer Judgement, IT-04-84-T, 3 April 2008.

Prosecutor v. Limaj, Trial Chamber Judgement, IT-03-66-T, November 20, 2005.

Rabkin, J. A.; Rabkin, A. To Confront Cyber Threats, We Must Rethink the Law of Armed Conflict. Koret-Taube Task Force on National Security and Law [interaktyvus]. [žiūrèta 2013-07-01]. <http://media. hoover.org/sites/default/files/documents/ EmergingThreats_Rabkin.pdf $>$.

Rauscher, K. F.; Korotkov, A. Working towards rules for governing cyber conflict. Rendering the Geneva and Hague Conventions in Cyberspace. New York: EastWest Institute, 2011.

Schmitt, M. N. "Attack" as a Term of Art in International Law: The Cyber Operations Context. 2012 4th International Conference on Cyber Conflict Proceedings. Czosseck, C.; Ottis, R.; Ziolkowski, K. (eds.). Tallinn: NATO CCD COE Publications, 2012.
Schmitt, M. N. Computer Network Attack and the Use of Force in International Law: Thoughts on a Normative Framework. Columbia Journal of Transnational Law. 1998-1999, 37: 885-938.

Tallinn Manual on the international Law Applicable to Cyber Warfare. Schmitt, M. N. (ed.). Cambridge University Press, 2013.

Traynor, I. Russia accused of unleashing cyberwar to disable Estonia. The Guardian [interaktyvus]. [žiūrèta 2013-07-01]. <http:// www.guardian.co.uk/world/2007/may/17/ topstories3.russia>.

Watts, S. The Notion of Combatancy in Cyber Warfare Watts. 2012 4th International Conference on Cyber Conflict Proceedings. Czosseck, C.; Ottis, R.; Ziolkowski, K. (eds.). Tallinn: NATO CCD COE Publications, 2012.

Ziolkowski, K. Ius ad bellum in Cyberspace Some Thoughts on the "Schmitt-Criteria" for Use of Force. 2012 4th International Conference on Cyber Conflict Proceedings. Czosseck, C.; Ottis, R.; Ziolkowski, K. (eds.). Tallinn: NATO CCD COE Publications, 2012.

\title{
THE INFLUENCE OF USING CYBER TECHNOLOGIES IN ARMED CONFLICTS ON INTERNATIONAL HUMANITARIAN LAW
}

\author{
Justinas Žilinskas \\ Mykolas Romeris University, Lithuania
}

Summary. Cyber warfare is becoming a new reality with new battles fought everyday on virtual battlefields. For a century and a half, International Humanitarian Law has been a sentry for victims of wars guaranteeing their legal protection from the calamities of war, trying hard to respond to Clausewitz's "chameleon of war". Cyber conflict marks new chameleon's colour together with the unmanned aerial vehicles, autonomic battle systems and other technologies deployed on battlefields. However, it would be greatly erroneous to claim that the International Humanitarian Law may not apply to the new phenomena just because it is caused by the advanced technology. Even if the Geneva Conventions of 1949 are already sixty years old, the International Humanitarian Law in itself has at minimum customary response 
mechanism, granting, in a spirit of Marten's clause, protection and authority of the principles of international law derived from established custom, from the principles of humanity and from dictates of public conscience (Protocol I).

Notwithstanding, some more complicated fundamental issues also have to be addressed: how the use of cybernetic weapons and means may affect the classic notion of armed conflict? How it can be interpreted in the light of new technologies, i.e. can we still rely on a classic understanding of weapon's kinetic effect as the main element, or shall we embrace effectsbased "Schmitt's criteria". If it so happens, will it make an act without apparent damage to a person/property equal to military hostilities, required by the armed conflict notion and justify the real-life response to it. The effective or overall control tests were used for the attribution of non-state actor's activity to the state party of an armed conflict but these tests might not meet its purpose in the virtual battlefield of loose networks and open-source communities. If the concept of armed conflict is treated more flexibly, other changes (including issues of attribution) may follow, as well. Perhaps this is the way how the combatant institute will evolve. With classic combatant's criteria impossible to apply on virtual battlefields, one of the options would be to elaborate concepts of "constant combat function" and "direct participation in hostilities" more precisely, as well as to reconsider state's affliation requirements.

Keywords: armed conflict, cyber conflict, international humanitarian law, cyber weapon.

Justinas Žilinskas, Mykolo Romerio universiteto Teisès fakulteto Tarptautinès ir Europos Sajungos teisès instituto profesorius. Mokslinių tyrimų kryptys: tarptautinė humanitarinè teisè, naujieji ginkluotieji konfliktai, Tarptautinis baudžiamasis teismas.

Justinas Žilinskas, Mykolas Romeris University, Faculty of Law, Institute of International and European Union Law, Professor. Research interests: international humanitarian law, modern armed conflicts, International Criminal Court. 